\title{
Combined therapy with disintegrin and melphalan as a new strategy in inhibition of endometrial cancer cell line (Ishikawa) growth
}

\author{
Wojciech Miltyk¹, Arkadiusz Surażyński², Wołczyński Sławomir³, Jerzy A. Pałka² \\ ${ }^{1}$ Department of Pharmaceutical Analysis, ${ }^{2}$ Department of Medicinal Chemistry, \\ ${ }^{3}$ Department of Gynecological Endocronology, Medical University in Bialystok, Bialystok, Poland
}

\begin{abstract}
Endometrial cancer is one of the most frequently diagnosed cancer in females with prevalence of 22 in 100,000 women. The etiology of the cancer remains unclear. Despite significant progress towards understanding the patho-mechanism of the disease, effective treatment is still lacking. The results of the study suggest that combined treatment of Ishikawa cells for $24 \mathrm{~h}$ with disintegrin and then for $24 \mathrm{~h}$ with melphalan severely inhibits important biological functions of the cells. We showed that such strategy have a potent cytotoxic effect. The mechanism of process undergoes probably through inhibition of integrin - dependent signaling. In this study we shown down regulation of Shc and FAK proteins in cells treated with echistatin and melphalan. It suggests that signaling pathways that involve She and FAK participation may represent target for antineoplastic strategy. The functional significance of the combined treatment of Ishikwa cells with echistatin and melphalan was found at the level of collagen biosynthesis. Decreased biosynthesis of collagen in extracellular matrix may suppress cell growth and induce apoptosis. The treatment with echistatin and melphalan also showed decreased expression of IGF receptor in comparison to the cells treated with both compounds separately. The data presented suggest that combined therapy with disintegrin - echistatin and alkyalting drug - mephalan may represent a new approach to more effective and safe cancer therapy.
\end{abstract}

Key words: echistatin, melphalan, Ishikwa cell line, $\beta_{1}$-integrin, cytotoxicity, collagen.

\section{Introduction}

Endometrial cancer is one of the most frequently diagnosed cancer in females with prevalence of 22 in 100,000 women [1]. According to NIH report in USA in 2008 developed approximately 35000 new cases of the disease and 7500 women died. Most cases occur in women at the age over 60 . The etiology of the cancer remains unclear. Despite significant progress towards understanding the patho-mechanism of the disease, effective treatment is still lacking.

Chemotherapy is indicated as frontline treatment for endometrial cancer. Combination of Anthracyclines, platinum compounds, and taxanes produces higher response rates, although combination regimens have not always improved survival rate. Doxorubicin plus cisplatin has been accepted as the Gynecologic Oncology Group standard regimen based on phase

Correspondence: W. Miltyk, Dept. of Pharmaceutical Analysis, Medical University in Bialystok, Kilinskiego Str. 1, 15-089 Bialystok, Poland; tel.: (+4885) 7485706, fax.: (+4885) 8795703, e-mail: wmiltyk@umwb.edu.pl
III clinical data. Hormonal therapy is beneficial only in specified group of patients [2].

From previous experiments it is known, that echistatin an inhibitor of $\beta_{1}$-integrin receptor contributes to inhibition of collagen biosynthesis and decrease in the expression of FAK, SOS-protein and phosphorylated MAP-kinases, ERK1 and ERK2 [3]. Stimulated $\beta_{1}$-integrin receptor induces autophosphorylation of non-receptor protein kinase FAK [4], which is then capable of interacting with adaptor-proteins, such as Grb2, through Src and Shc proteins. This interaction allows activating further cascade of signaling pathway through Sos, Ras and Raf proteins [5] and subsequently, two MAP kinases: $\mathrm{ERK}_{1}$ and $\mathrm{ERK}_{2}$ [6]. The end point of this cascade is induction of transcription factor(s) that regulate(s) gene expression of integrins, proteinases and many proteins involved in regulation of cell growth and differentiation [7].

Another potent stimulator of cell growth and collagen biosynthesis is insulin like growth factor I [8]. IGFI interacting with its receptor stimulates proliferation, enhances metastasis [9], prevents apoptosis [10]. IGF receptor signaling pathway involves the same proteins 
as integrin receptor signaling cascade, except $\mathrm{Src}$ and FAK proteins [11].

Melphalan represents one of nitrogen mustard derivates, the group of earliest and effective antitumor drugs used in cancer therapy [12]. It acts through formation of interstrand cross-links in major groove of DNA [13]. Melphalan also inhibits collagen biosynthesis in breast cancer cell lines [14] and was also proposed as a component of combined therapy in metastatic or recurrent endometrial carcinoma [15].

The present study was undertaken to evaluate the effect of combined treatment of disintegrin, echistatin and melphalan on collagen biosynthesis, expressions of $\beta_{1}$-integrin and IGF-I receptors and some signaling proteins as Shc protein and FAK-kinases as well as on cytotoxicity in endometrial cancer (Ishikawa) cells.

\section{Materials and methods}

Materials. Anti-Goat IgG antibody, Anti-Mouse IgG antibody, Fast BCIP/NBT reagent, Nonidet P-40, were provided by Sigma Corp., USA., as were most other chemicals and buffers used. Dulbecco's minimal essential medium (DMEM) and fetal bovine serum (FBS) used in cell culture were products of Gibco, USA. Glutamine, penicillin and streptomycin were obtained from Quality Biologicals Inc., USA. Nitrocellulose membrane $(0,2 \mu \mathrm{m})$, sodium dodecylsulphate (SDS), polyacrylamide, molecular weight standards were received from Bio-Rad Laboratories, USA. L-5 $\left[{ }^{3} \mathrm{H}\right]$ proline $(28 \mathrm{Ci} / \mathrm{mmol})$ was purchased from Amersham, UK. Monoclonal (mouse) antiIGFR, anti Shc, anti-FAK antibodies were obtained from Becton Dickinson Co., USA. Monoclonal (mouse) anti- $\beta_{1}$-integrin antibody was obtained from ICN Biomedicals Inc., USA.

Tissue culture. All studies were performed on Ishikawa cell line purchased in American Type Culture Collection, Rockville, MD. The cells were maintained in DMEM supplemented with 5\% fetal bovine serum (FBS), $2 \mathrm{mmol} / 1$ glutamine, $50 \mathrm{U} / \mathrm{ml}$ penicillin, $50 \mu \mathrm{g} / \mathrm{ml}$ streptomycin at $37^{\circ} \mathrm{C}$ in a $5 \% \mathrm{CO}_{2}$ incubator.

Cytotoxicity assay. Toxicity of evaluated compounds was determined by method of Plumb et al. [16]. Iskikawa cells were maintained as described above. After $48 \mathrm{~h}$ incubation of the cells with drugs the medium was discarded and the cells were rinsed three times with phosphate buffered saline (PBS). Then the cells were incubated for $4 \mathrm{~h}$ in $2 \mathrm{ml}$ of PBS with $50 \mu \mathrm{l}$ of MTT $(5 \mathrm{mg} / \mathrm{ml})$. Medium was removed from the wells, and the cells were lyzed in $200 \mu \mathrm{l}$ of DMSO with $20 \mu \mathrm{l}$ of Sorensen's buffer $(0.1 \mathrm{M}$ glycine with $0.1 \mathrm{M}$ $\mathrm{NaCl}, \mathrm{pH} 10.5)$. The absorbance was measured at $570 \mathrm{~nm}$.

Collagen production. Incorporation of radioactive precursor into proteins was measured after labeling of confluent cells in growth medium with evaluated compounds for $48 \mathrm{~h}$ with $5\left[{ }^{3} \mathrm{H}\right]$-proline $(5$ $\mu \mathrm{Ci} / \mathrm{ml}, 28 \mathrm{Ci} / \mathrm{mM}$ ) as described by Peterkofsky et al. [17].

SDS-PAGE. Slab SDS/PAGE was used, according to the method of Laemmli [18]. Samples of cell supernatants $(25-50 \mu \mathrm{g}$ of protein) were incubated for $10 \mathrm{~min}$. at $100^{\circ} \mathrm{C}$ in $62.5 \mathrm{mmol} / 1 \mathrm{Tris}-\mathrm{HCl}$, $\mathrm{pH} 6.8$, containing $2.0 \%(\mathrm{w} / \mathrm{v}) \mathrm{SDS}, 5 \%(\mathrm{v} / \mathrm{v}) \boldsymbol{\beta}$-mercaptoethanol, $10 \%(\mathrm{v} / \mathrm{v})$ glycerol and $0.001 \%$ bromophenol blue. Samples were electrophoresed on a Tris-Glycine gels at $100 \mathrm{~V}$ per gel for $30 \mathrm{~min}-$ utes at room temperature.

Western immunoblot analysis. After SDS-PAGE, the gels were allowed to equilibrate for $5 \mathrm{~min}$ in $25 \mathrm{mmol} / 1$ Tris, $0.2 \mathrm{~mol} / 1$ glicine in $20 \%(\mathrm{v} / \mathrm{v})$ methanol. The protein was transferred to $0.2 \mu \mathrm{m}$ pore- sized nitrocellulose at $100 \mathrm{~mA}$ for 90 minutes using a BioRad electrophoresis unit according to the method described in the manual accompanying the unit. The membrane was blocked with $5 \%$ dried milk in TBS-T for 1 hour in room temperature, slowly shaking. Then the nitrocellulose was incubated with monoclonal antibody against $\beta_{1}$-integrin, FAK, Shc or IGFR at concentration 1:5,000 overnight. After the incubation, nitrocellulose was washed with TBS-T ( 1 x 15 min and $2 \times 10$ min) intensively shaking. In order to analyze the proteins second alkaline phosphatase labeled antibodies against mouse's Fc IgG was added at concentration 1:2,500 in TBS-T and incubated for 1 hour slowly shaking. Then the membrane was extensively washed with TBS-T (5 x $10 \mathrm{~min})$ and submitted to BCIP/NBT western blotting detection system.

Statistical analysis. In all experiments, the mean values for three independent experiments \pm standard deviation were calculated. The results were submitted to statistical analysis using Student's ttest, accepting $\mathrm{p}<0.05$ as significant.

\section{Results}

To evaluate cytotoxic effect of echistatin and melphalan, the viability of Ishikawa cells was measured by the method of Plumb et al. [16]. Incubation of the cells for $24 \mathrm{~h}$ with disintegrin at concentrations 50 and $100 \mathrm{ng} / \mathrm{ml}$ of medium had no significant effect on the cell viability (Fig. 1). Melphalan at concentrations 25, 50 and $75 \mu \mathrm{M}$ induced decreased of the cell viability to 89,82 and $76 \%$ of control value, respectively. Incubation of Ishikawa cells with $50 \mathrm{ng} / \mathrm{ml}$ or $100 \mathrm{ng} / \mathrm{ml}$ of echistatin for $24 \mathrm{~h}$ and then incubated for additional $24 \mathrm{~h}$ with 25,50 or $75 \mu \mathrm{M}$ melphalan significantly decreased the cell viability (Fig. 1). Different order of added substrances produced much lower effects (not shown).

Similar effect was observed in respect to collagen biosynthesis. The inhibition of the protein biosynthesis was the most effective when the cells were treated with disintegrin for $24 \mathrm{~h}$ and then with melphalan for $24 \mathrm{~h}$ (Fig. 2).

Collagen biosynthesis is regulated by the signal induced by $\beta_{1}$-integrin receptor. Expression of the receptor was evaluated by western immunoblot analysis. Expression of the $\beta_{1}$-integrin was not changed in Ishikawa cell line treated with echistatin, melphalan or both compounds (Fig. 3).

Expression of proteins involved in signaling pathway induced by stimulated $\beta_{1}$-integrin receptor was also evaluated. (Fig. 4) Treatment of the cells with echistatin for 24 hours and then with melphalan, induced decrease in the expression of Shc and phosphorylated FAK-proteins as compared to control cells or the cells treated with both compounds alone (Fig. 4).

Since IGF-I receptor plays important role in regulation of mitogenesis, apoptosis and collagen biosynthesis the expression of the receptor in Ishikawa cell line treated with echistatin and melphalan was estimated. As shown on Fig. 5. the expression of the receptor was decreased in the cells treated with echistain for $24 \mathrm{~h}$ and 


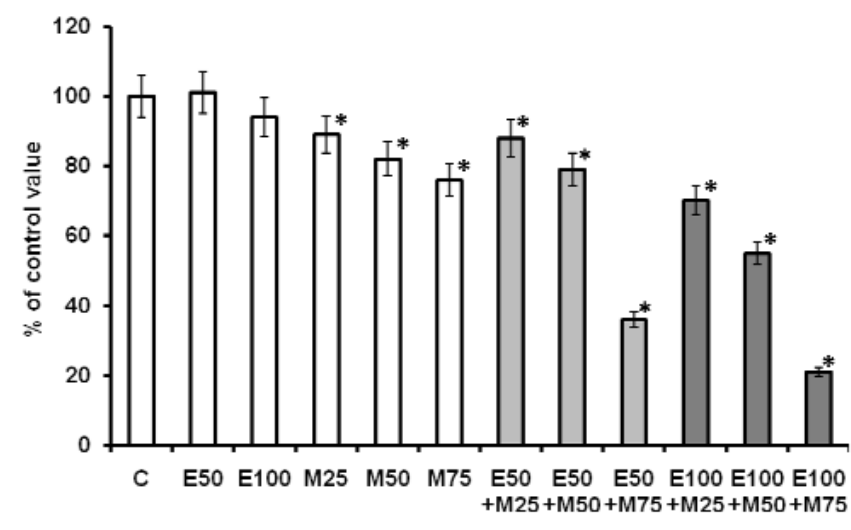

Fig. 1. Viability of Ishikawa cells treated with various concentrations of echistatin (E) and malphalan (M). The cells were incubated for $48 \mathrm{~h}$ with echistatin at concentrations 50 and $100 \mathrm{ng} / \mathrm{ml}$ condition medium or melphalan at concentrations 25,50 and $75 \mu \mathrm{M}$. Another set of the cells was treated with $50 \mathrm{ng} / \mathrm{ml}$ or $100 \mathrm{ng}$ of echistatin for 24 hours then melphalan was added to achieve concentrations 25,50 and $75 \mu \mathrm{M}$, incubation continued for 24 hours. Mean values from three independent experiments done in triplicates $+/$ - standard deviation are presented. ${ }^{*} \mathrm{p}<0.05$.

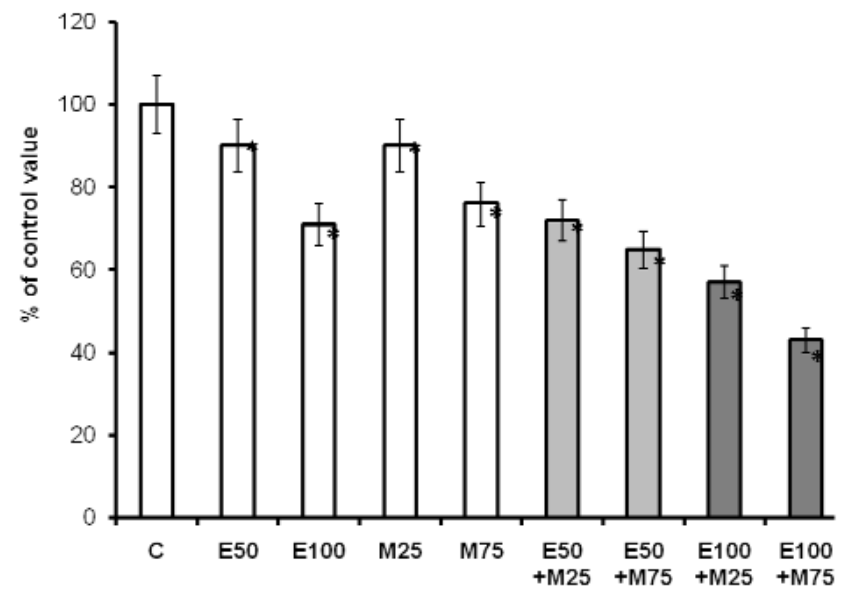

Fig. 2. Collagen production, measured by $5-\left[{ }^{3} \mathrm{H}\right]$-proline incorporation into proteins susceptible to the action of bacterial collagenase in Ishikawa cell culture. The cells were incubated for $48 \mathrm{~h}$ with echistatin at concentrations 50 and $100 \mathrm{ng} / \mathrm{ml}$ condition medium or melphalan at concentrations 25,50 and $75 \mu \mathrm{M}$. Another set of the cells was treated with $50 \mathrm{ng} / \mathrm{ml}$ or $100 \mathrm{ng}$ of echistatin for 24 hours then melphalan was added to achieve concentrations 25,50 and $75 \mu \mathrm{M}$, incubation continued for 24 hours. Mean values from three independent experiments done in triplicates $+/$ - standard deviation are presented. ${ }^{*} \mathrm{p}<0.05$.

than with melphalan for additional $24 \mathrm{~h}$. Treatment of the cells with respective compound alone had no effect on the IGF receptor protein expression.

\section{Discussion}

The integrins familly are responsible for adhesion of cells to extracellular matrix components as well as to
A

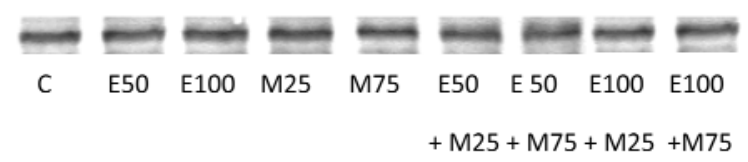

B

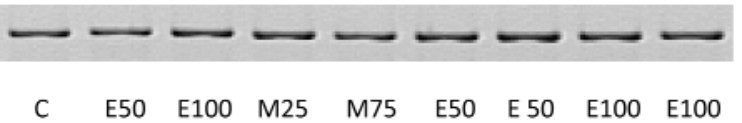

Fig. 3. Western immunoblot analysis for $\beta_{1}$-integrin receptor (A) in Ishikawa cells treated with echistatin (E) and melphalan (M). $\beta$ actin serves as a loading control (B). The result represent mean from three independent experiments. Samples used to the experiments consisted $50 \mu \mathrm{g}$ of protein from pooled cell extracts.

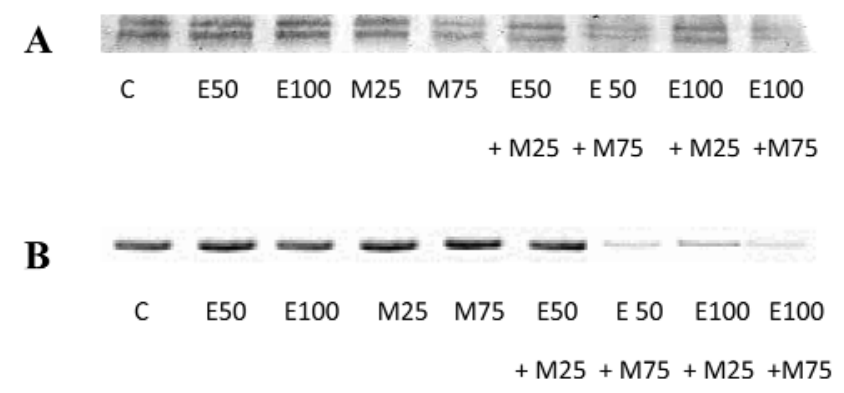

Fig. 4. Western immunoblot analysis for She protein (A), FAK (B) in Ishikawa cells treated with echistatin (E) and melphalan (M) as described in Materials and methods section. The result represent mean from three independent experiments. Samples used to the experiments consisted $50 \mu \mathrm{g}$ of protein from pooled cell extracts.

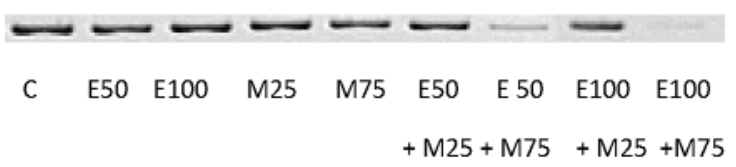

Fig. 5. Western immunoblot analysis for IGF receptor in Ishikawa cells treated with echistatin (E) and melphalan (M) as described in Materials and methods section. The result represent mean from three independent experiments. Samples used to the experiments consisted $50 \mu \mathrm{g}$ of protein from pooled cell extracts.

other cells [19]. The interaction affects cytoskeleton organization, lipid metabolism, kinase activation, gene expression [20], cell cycle progression [21] and metastasis [22]. $\beta_{1}$ and $\beta_{3}$ integrins play an important role in tumor invasion [23].

Cell migration, invasion, matrix degradation, proliferation, and angiogenesis are all mediated by integrins and integrin signaling $[24,25]$.

Ishikawa cells, similarly as endometrial, epithelial cells express integrins $\alpha_{2} \beta_{1} \alpha_{3} \beta_{1}, \alpha_{6} \beta_{4}$ [26]. $\alpha_{2} \beta_{1}$ integrin receptor is the main receptor for collagen and is involved in regulation of collagen production [27].

Melphalan is one of the nitrogen mustard derivatives, that represent the group of earliest and effective 
antitumor drugs used in cancer therapy [12,13], acting through induction of interstrand cross-links in major groove of DNA [12,13]. Melphalan is used in therapy of advanced cancer of the ovaries, multiple myeloma, malignant melanoma, childhood neuroblastoma, soft tissue sarcoma. Side effects of melphalan include toxicity on blood cells, platelets, lung and liver and may contribute to nausea, diarrhea, mouth ulcers, hair loss, skin rashes and leukaemia. It is extremely important to keep doses of anticancer drug as low as possible to avoid serious side effects.

Echistatin and other disintegrins have been extensively studied in the past. It is now established that disintegrins are effective agents in limiting tumor growth and spread $[28,29]$. Disintegrins interacting with several integrins block various integrin-mediated processes involved in tumor growth, metastasis and angiogenesis [30].

The results of the study suggest that combined treatment of Ishikawa cells with echistatin and melphalan severely inhibits important biological functions of the cells. We showed that such strategy have a potent cytotoxic effect. The mechanism of the process undergoes probably through inhibition of integrin - dependent signaling. In this study we shown down regulation of She and FAK proteins in cells treated with echistatin and melphalan. It suggests that signaling pathways that involve Shc and FAK participation may represent target for antineoplastic strategy.

The functional significance of the combined treatment of Ishikwa cells with echistatin and melphalan was found at the level of collagen biosynthesis. Decreased biosynthesis of collagen in extracellular matrix on one hand may faciliate motility and invasion of neoplastc cells (31), but on another may suppress cell growth and induce apoptosis [32].

Important role in induction of those processes may play also IGF-I receptor. The cells treated for $24 \mathrm{~h}$ with disintegrin and then for $24 \mathrm{~h}$ with melphalan showed decreased expression of IGF receptor in comparison to the cells treated with both compounds separately. IGF-R is involved in regulation of cellular growth and transformation [33]. Therefore inhibition of the receptor expression may represent approach to the inhibition of tumor growth. Blockade of the receptor (34) or down regulation of its expression [35] reduces cancer proliferation and induces apoptosis. Decreased expression of the receptor by echistatin and melphalan could explain decreased biosynthesis of collagen in the cells, since IGF-I is a most potent inducer of collagen biosynthesis [36].

Finally, echistatin (that by itself is only slightly cytotoxic for Ishikawa cells) strongly potentiate cytotoxic effect of melphalan on this cells.

The data presented suggest that combined therapy with disintegrin - echistatin and alkyalting drug - mephalan may represent a new approach to more effective and safe endometrial cancer therapy.

\section{References}

[1] Arnold TJ, Lessey AB, Seppa M, Kaufman GD. Effect of Normal Endometrial Stroma on Growth and Differentiation in Ishikawa, Endometrial Adenocarcinoma Cells. Cancer Research. 2002;62:79-88.

[2] Obel JC, Friberg G, Fleming GF, Chemotherapy in endometrial cancer. Clin Adv Hematol Oncol. 2006;4:459-68.

[3] Surazyński A, Sienkiewicz P, Wołczyński S, Pałka J. Differential effects of echistatin and thrombin on collagen production and prolidase activity in human dermal fibroblasts and their possible implication in betal-integrin-mediated signaling. Pharmacol Res. 2005;51:217-21.

[4] Hanks SK, Calalb MB, Harper MC, Patel SK. Focal adhesion protein-tyrosine kinase phosphotylated in response to cell attachment to fibronectin. Proc Natl Acad Sci USA. 1992;89:8487-91.

[5] Juliano R. Cooperation between soluble factors and integrinmediated cell anchorage in the control of cell growth and differentiation. Bioessays. 1996;18:911-7.

[6] Seger R, Krebs EG. The MAPK signaling cascade. FASEB J. 1995;9:726-35.

[7] Labat-Robert J, Robert L. Interaction between cells and extracellular matrix: signaling by integrins and the elastin-laminin receptor. Prog Mol Subcell Biol. 2000;25:57-70.

[8] Goldstein RH, Poliks CF, Plich PF, Smith BD, Fine A. Stimulation of collagen formation by insulin-like growth factor-I in cultures of human lung fibroblasts. Endocrinology. 1989; 124:964-70.

[9] Le Roith D, Werner H, Beitner-Johnson D, Roberts Jr CT. Molecular and cellular aspects of the insulin-like growth factor-I receptor. Endocr Rev. 1995;16:143-64.

[10] Gross JM, Yee D. The type-1 insulin-like growth factor receptor tyrosine kinase and breast cancer: biology and therapeutic relevance. Cancer Metastasis Rev. 2003;22:327-36.

[11] Butler AA, Shoshana Y, Gewolb IH, Karas M, Okubo Y, LeRoith D. Insulin-like growth factor-I receptor signal transduction: at the interface between physiology and cell biology. Comp Biochem Physiol B. 1998;121:19-26.

[12] Farmer PB. Metabolism and reactions of alkylating agents. Pharmacol Therap. 1987;35:301-58.

[13] Rothbarth J, Koevoets C, Tollenaar R, Tilby MJ, van de Velde CJH, Mulder GJ, et al. Immunohistochemical detection of melphalan-DNA adducts in colon cancer cells in vitro and human colorectal liver tumours in vivo. Biochem Pharmacol. 2004;67:1771-8.

[14] Bielawski K, Bielawska A, Sosnowska K, Miltyk W, Winnicka K, Pałka J, Novel amidine analogue of melphalan as a specific multifunctional inhibitor of growth and metabolism of human breast cancer cells, Biochemical pharmacology. 2006;72:320 - 331 .

[15] Cornelison TL, Baker TR, Piver MS, Driscoll DL. Cisplatin, adriamycin, etoposide, megestrol acetate versus melphalan, 5-fluorouracil, medroxyprogesterone acetate in the treatment of endometrial carcinoma. Gynecol Oncol. 1995;59:243-8.

[16] Plumb, JA, Milroy R, Kaye SB. Effects of the $\mathrm{pH}$ dependence of 3-(4,5-dimethylthiazol-2-yl)-2,5-diphenyltetrazolium bromide-formazan absorption on chemosensitivity determined by a novel tetrazolium-based assay. Cancer Research. 1989;49: 4435-4440.

[17] Peterkofsky B, Palka J, Wilson S, Takeda K, Shah V. Elevated activity of low molecular weight insulin-like growth factorbinding proteins in sera of vitamin C-deficient and fasted guinea pigs. Endocrinology. 1991;128:1769-79. 
[18] Laemmli UK. Cleavage of structural proteins during the assembly of the head of bacteriophage T4. Nature 1970;227:680-685.

[19] Hanks SK, Calalb MB, Harper MC, Patel SK. Focal adhesion protein-tyrosine kinase phosphotylated in response to cell attachment to fibronectin. Proc Natl Acad Sci USA. 1992;89:8487-91.

[20] Meredith Jr JE, Winitz S, Artur Lewis J, Hess S, Xiang-Dong $\mathrm{R}$, Renshaw MW, et al. The regulation of growth and intracellular signaling by integrins. Endocr Rev. 1996;17:207-20.

[21] Adams JC. Cell-matrix contact structures. Cell Mol Life Sci. 2001;58:371-92.

[22] Bosco M, Chan C, Matsuura N, Tokada Y, Zetter BR, Hemler ME. In vitro and in vivo consequences of VLA-2 expression on rhabdomyosarcoma cells. Science. 1991;25:1600-1602.

[23] Kramer RH, Vu M, Cheng YF, Ramos DM. Integrin expression in malignant melanoma. Cancer Metastasis Rev. 1991;10:49-59.

[24] Giancotti FG, Mainiero F. Integrin-mediated adhesion and signaling in tumorigenesis. Biochim Biophys Acta. 1994;1198:47-64.

[25] Varner JA, Cheresh DA. Integrins and cancer. Curr Opin Cell Biol. 1996;8:724-30.

[26] Castelbaum AJ, Ying L, Somkuti SG, Sun J, Ilesanmi AO, Lessey BA. Characterization of integrin expression in a well differentiated endometrial adenocarcinoma cell line (Ishikawa). J Clin Endocrinol Metab. 1997;82:136-42.

[27] Ivaska J, Reunanen H, Westermarck J, Koivisto L, Kahari VM, Heino J. Integrin alpha2beta1 mediates isoform-specific activation of p38 and up-regulation of collagen gene transcription by a mechanism involving the alpha 2 cytoplasmic tail. J Cell Biol. 1999;147:401-16.
[28] Zhou Q, Sherwin RP, Parrish C, et al. Contortrostatin, a dimeric disintegrin from Agkistrodon contortrix contortrix, inhibits breast cancer progression. Breast Cancer Res Treat. 2000;61:249-60.

[29] Zhou Q, Shieh KY, Markland FS. Contortrostatin (CN), a dimeric disintegrin inhibits invasion of ovarian cancer by blocking integrin avb5. Proc Am Assoc Cancer Res. 2000;41:800.

[30] Swenson S, Costa F, Minea R,1 Sherwin RP, Ernst W, Fujii G, Yang D, Markland FS Jr. Intravenous liposomal delivery of the snake venom disintegrin contortrostatin limits breast cancer progression, Mol Cancer Ther. 2004;3:499-511.

[31] Perumpanani AJ, Byrne HM. Extracellular matrix concentration exerts selection pressure on invasive cells. Eur J Cancer. 1999;35:1274-80.

[32] Boudreau N, Bissel MJ. Extracellular matrix signaling: integration of form and function in normal and malignant cells. Curr Opin Cell Biol. 1998;10:640-6.

[33] Baserga R, Hongo A, Rubini M, Prisco M, Valentinis B. The IGF-I receptor in cell growth, transformation and apoptosis. Biochem Biophys Acta Rev Cancer. 1997;1332:105-6.

[34] Maloney EK, McLaughlin JL, Dagdigian NE, Garrett LM, Connors KM, Zhou XM, et al. An anti-insulin-like growth factor I receptor antibody that is a potent inhibitor of cancer cell proliferation. Cancer Res. 2003;63:5073-83.

[35] Xie SP, Pirianov G, Colston KW. Vitamin D analogues suppress IGF-I signaling and promote apoptosis in breast cancer cells. Eur J Cancer. 1999;35:1717-23.

[36] Goldstein RH, Poliks CF, Plich PF, Smith BD, Fine A. Stimulation of collagen formation by insulin-like growth factor-I in cultures of human lung fibroblasts. Endocrinology. 1989;124:964-70. 